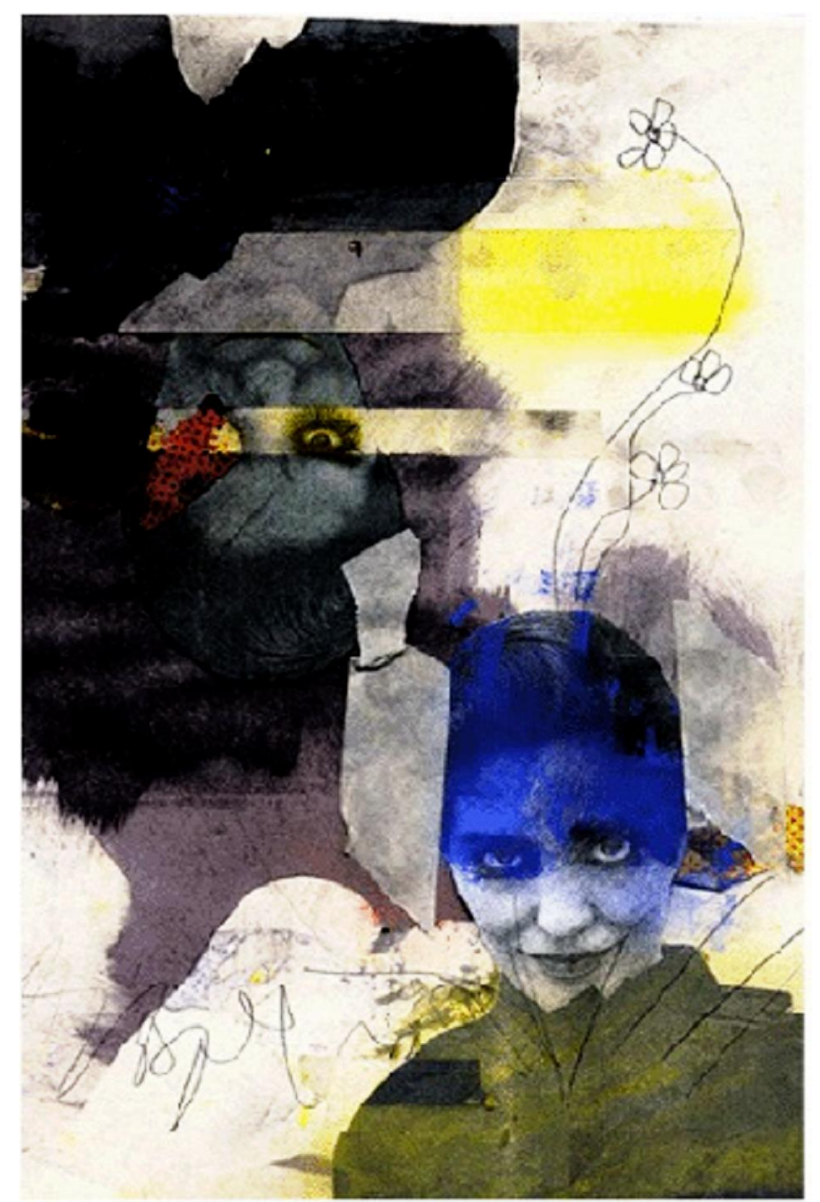

João Paulo Tiago

\title{
A televisão na escola: novos modos de leitura
}

\section{Lavínia Resende Passos}

Mestranda em Teoria de Literatura pela Universidade Federal de Minas Gerais. Desenvolve pesquisa na área de Literatura e outros sistemas semióticos, analisando contos que foram adaptados para o cinema. Foi bolsista do CNPq durante um ano desenvolvendo a pesquisa As telas - cinema e televisão - como instrumentos de recepção dos contos de Luiz Vilela. É integrante do Programa A tela e o texto desde 2005.

NAGAMINI, Eliana. Literatura, televisão, escola: estratégias para leitura de adaptações. São Paulo: Cortez, 2004. (Coleção aprender e ensinar com textos; v. 11. Coordenação geral: Adilson Citelli e Ligia Chiappini). 
O livro Literatura, televisão, escola: estratégias para leitura de adaptações faz parte da coleção "Aprender e ensinar com textos". Toda a coleção é formada por trabalhos acadêmicos que tratam de assuntos relacionados à educação e que abordam principalmente as áreas da linguagem, da literatura e da comunicação. Os textos fundem as pesquisas desenvolvidas às experiências na sala de aula e têm como público-alvo os educadores.

De forma simples, com uma linguagem acessível não só ao professor da academia mas aos educadores em geral, Eliana Nagamini toca em um ponto crucial do sistema educacional de hoje - a formação do leitor - que, atualmente, deve considerar os conceitos ampliados de leitura, associando as estratégias de decodificação do texto aos recursos da mídia. O trabalho desenvolvido em Literatura, televisão, escola aborda essa pedagogia e mostra como a adaptação de uma obra literária para a televisão pode ser útil na formação do aluno-leitor. Didaticamente, a autora não só faz a análise da adaptação, mas também sugere atividades para serem desenvolvidas em sala de aula.

- primeiro capítulo faz uma abordagem teórica do gênero romance, mais especificamente do romance folhetim, e também uma abordagem histórica das adaptações desse gênero para a televisão. Essas análises têm como objeto de estudo o romance Memórias de um sargento de milícias, de Manuel Antônio de Almeida, e suas adaptações para o teatro e para a TV. Ao analisar a obra e suas adaptações, a autora nos fornece reflexões importantes sobre a adequação da linguagem ou do espaço literários ao novo código/veículo.

Nos segundo e terceiro capítulos, Nagamini desenvolve uma análise específica de Vidigal, nome que o texto recebeu em sua adaptação para a televisão. Nessa parte, ela faz uma detalhada descrição das ações narrativas e dos personagens, apontando semelhanças e diferenças entre o texto verbal e o texto televisivo. Além disso, aborda os programas televisivos (ressaltando inclusive seus aspectos técnicos) que trazem em seu conteúdo as adaptações literárias, como é o caso das minisséries e dos especiais. A análise nessa parte se tornaria um pouco cansativa, se não houvesse imagens ilustrativas das descrições.

Já o capítulo quatro, com base nas teorias dos capítulos anteriores, volta-se exclusivamente para a análise dos personagens, o que mais uma vez ressalta o caráter didático do livro. Com quadros/esquemas, a autora mostra toda a montagem dos personagens (tanto dos personagens do filme, quanto do 
teatro e, por fim, da TV), examinando suas ações e relações mútuas. Assim, consegue clarear suas próprias afirmações relativas à manutenção ou não de determinados personagens na adaptação, tendo em vista as questões do tempo, do espaço ou da nova narrativa que se instala.

No capítulo cinco, Nagamini discute o uso da adaptação na sala de aula. É importante salientar que a autora em momento algum vê a adaptação como uma substituta da obra verbal, mas como seu complemento, como técnica capaz de despertar interesse inclusive para a leitura do texto original.

Nos capítulos seguintes, a autora vai além do estudo do romance e aborda a adaptação do conto, da peça teatral, da crônica, da poesia e de mais um romance. Em todos os gêneros, a autora oferece a ficha técnica do filme, alguns recortes do texto verbal ou do roteiro adaptado, ilustrações, comentários e sugestões para o trabalho em sala de aula. Em cada gênero, ela ressalta uma particularidade a ser trabalhada: construção de personagens, estrutura narrativa, uso de linguagem, metalinguagem e paródia, análise do tempo e do espaço. O fato de a obra oferecer sugestões de trabalho é interessante, pois são concretizadas assim, as idéias apresentadas na parte teórica.

Ao pensarmos num país como o Brasil, que possui altas taxas de analfabetismo e uma cultura predominantemente televisiva, a adaptação de obras canônicas da Literatura Brasileira para esse suporte contribui enormente para a formação de leitores, sejam eles alunos ou professores. Nesse caso, um aspecto interessante citado pela autora é a lista de programas da TV Escola que discute as relações entre linguagem visual e literária. Além disso, ela oferece endereços de sites que tratam do tema, mostrando, mais uma vez, como os recursos da atualidade, utilizados de maneira correta, podem funcionar como ponto de referência para os educadores.

Literatura, televisão, escola: estratégias para leitura de adaptações mostra como é possível trabalhar em sala de aula com recursos audiovisuais, investindo na formação de leitores interativos e críticos, capazes, portanto, de decifrar a avalanche de textos/discursos da atualidade. 